Research Article

\title{
Comparison of Staple Food Availability in Urban and Rural Households in Kabupaten Malaka
}

Falentina Adriana Nahak a,1,*, Johanna Suek b,2, Lika Bernadina b,3

a,b,c Program Studi Agribisnis Fakultas Pertanian Universitas Nusa Cendana, Jl Adi Sucipto Penfui No.85001, Lasiana KIp. Lima, Kota Kupang, Nusa Tenggara Timur

1 adrianainanahak@gmail.com ; ${ }^{2}$ johanna.suek@staf.undana.ac.id ; 3 likabernadina01@gmail.com

Corresponding author

\begin{tabular}{|c|c|}
\hline ARTICLE INFO & ABSTRACT \\
\hline $\begin{array}{l}\text { Article history } \\
\text { Received February 23, } 2021 \\
\text { Revised August 27, 2021 } \\
\text { Accepted October 27, } 2021 \\
\text { Published October 28, } 2021 \\
\text { Keywords } \\
\text { Households } \\
\text { Urban } \\
\text { Rural } \\
\text { Availability }\end{array}$ & $\begin{array}{l}\text { This study aims to investigate the differences staple food availability and household } \\
\text { consumption patterns in urban and rural areas. This research took place in } \\
\text { Kabupaten Malaka, with the sample of } 60 \text { urban households and } 60 \text { households } \\
\text { chosen through random sampling. The obtianed data were analyzed qualitatively and } \\
\text { quantitatively. Results show that staple food availability respondents' household were } \\
\text { from the production of own farming, purchasing, and assistance from relatives. } \\
\text { However, the availability of staple food did not support household consumption needs } \\
\text { for } 365 \text { days ( } 1 \text { year). Staple food availability index in urban areas was } 58.4 \text {, and the } \\
\text { rural households reached } 57.2 \text {. These numbers were far below the national index of } \\
100 \text {. Analysis of z-tests showed significant differences in staple food availability } \\
\text { between urban and rural households. } \\
\text { This is an open access article under the CC-BY-SA license } \\
\text { Copyright } \text { 2021, Nahak et al }\end{array}$ \\
\hline
\end{tabular}

\section{INTRODUCTION}

Staple food is among essential human needs that is consumed regularly in sufficient quantities. According to Law No. 18 year 2012, staple food refers to daily main meal as a source of basic nutrition, but lacking of nutrition. Dewi and Purwidiani (2015) state that different communities across regions consume different staple food following the local and cultural conditions. In Indonesia, staple food includes rice, corn, cassava, and sago.

Food availability is critical to determine the fulfillment of food consumption. In household levels, food availability is fulfilled when the they can access and afford the food. Food accessibility can be obtained from farm production or purchasing (Apu et al., 2017). Fallo and colleagues (2019) denotes that food access and ability of each household highly depends on their income. It can also be influenced by the ownership of farming land to cultivate family food.

Households with sufficient resources can cope with local food instability and are able to maintain access to food. However, there are factors that may affect food availability in each household. Soemarno (2010) argues that household's food availability is strongly influenced by income and farming production. In this 
case, family income determines household's purchasing power, and thus their eating patterns and habits. This may result in similar food availability among households in a region. Reduced income caused by famine sometimes leads to food shortage. In a bigger scale, regional food deficit may occur, in which further impact eating habits. As a result, households with similar food availability in a particular region is equally affected by the famine, making them a food deficit area.

A current study by Pratiwi, Seran, \& Bano (2016) found that people of Kabupaten Malaka has potentially diverse natural resources, enabling them to be the powerful food providers to the larger areas. Among their superior products are bananas, corns, green beans, rice, sorghum, various types of tubers, and horticultural products. These products had been helping during famine, which normally caused food insecurity for urban community. Specifically, low-income urban people have less food access than rural communities, led them in troubles during famine. The data from Dinas Tanaman Pangan (2019) shows annual increases during 20132017 with an average increase of $49.5 \%$. This number only decreased in 2016 by $12.9 \%$ due to climate changes that affected regional crops and productivity.

Several studies on food availability by Rahayu (2014) constantly found that household's food availability is mainly supported by own production rather than purchases. This study is quantitaively supported by Fallo and colleagues (2019), which showed that the availability of household staple food was $276 \mathrm{~kg}$ of rice. This amount can only meet the needs for 207 days. Hence, food availability can be categorized as insufficient. Another study using the sample $t$-independent $(p>0.05)$ evidenced that food availability of rural areas was greater than urban areas (Apriani \& Baliwati, 2011).

In Kabupaten Ambarawa, Maiyani and colleagues (2017) found that household food availability only reached $67.99 \%$ of the AKE standard. It was shown that farmers' land areas and ages significantly affected the food availability. Banita (2013) also found that household food availability was moderate with rice as the main staple food. Pellokila, Oematan, and Kami (2020) explained that there is a positive correlation between household income and food availability.

Kabupaten Malaka is one of the Indonesia's outermost regions directly bordered with Timor Leste. It is largely potential in agricultural, consisting of people from various socio-economic layers determined through land ownership, education, job, income, and the number of family members. Such diversity creates differences in household supply and consumption. This issue underlies this present research that aims to describe the availability and differences in the level of household staple food availability in urban and rural areas of Kabupaten Malaka.

\section{METHODOLOGY}

The study was carried out in February to April 2020. Kabupaten Malaka was deliberately chosen by considering the accessibility. Kota Betun and Desa Naimana of Kabupaten Malaka were chosen. Stratification random sampling in urban and rural regions was employed. Participants from urban areas were stratified according to their jobs as civil servants ( 30 families), merchants ( 15 families), and private employees (15 families). In rural areas, the participants were stratified following their land areas, which were $<0.5$ ha $=15$ families; $0.51-1 \mathrm{ha}=20$ families; $1,1-2 \mathrm{ha}=10$ families; and $>2 \mathrm{ha}=15$ families. In total, there were 120 urban and rural households involved in this study. Primary data was obtained by interviewing households following structured and semi-structured interviews with closed and open questions.

The criteria of food availability refers to food adequacy according to Soemarno (2010), in which: a) the household food supply meet 365 days, which is adequate; b) the household food supply meets between 1 364 days, which is less adequate; and c) the household does not have a food supply, which is inadequate.

Food Consumption Patterns were analyzed based on PPH referring to BKP (2015). The analysis included: a) actual consumption; b) actual energy; c) actual percentage; d) AKE percentage; d) actual score; and e) AKE score. The calculation of PPH score follows the condition that the maximum score. $f$ the AKE 
score > maximum score, the maximum score is used. The Comparative Analysis of staple food availability of rural and urban households employed the z-test (Sudjana, 2002). Before the test, all agricultural products were converted to rice equivalent using the standard price of rice at the research site. The categorization of household food security refers to Bickel, Nord, Price, Hamilton, and Cook (2000) described as follows:

- Secure

If 2 out of 18 questions were answered with often, sometimes, and yes, almost every month, and some months but not every month.

- Prone to hunger, grouped into three categories, namely:

$\circ$ Mild hunger: if 3-5 out of 18 questions are answered with often, sometimes, and yes, almost every month, and some months but not every month.

- Moderate hunger: if 6-8 out of 18 questions are answered with often, sometimes, and yes, almost every month, and some months but not every month.

$\circ$ Severe hunger: if $>9$ out of 18 questions are answered with often, sometimes, and yes, almost every month, and some months but not every month.

\section{FINDINGS AND DISCUSSION}

\section{Respondent profile}

Respondent profile is the description of the situation and background of the household. The profiles include age, education, number of family members, farming experience, and area and status of land use.

It was found that the average age of respondents and their partners is relatively same in urban and rural areas: 45 years and 42 years, respectively. In urban areas, $52 \%$ of respondents are undergraduates, $27 \%$ are high school graduates, and the remaining $20 \%$ are elementary and junior high school graduates. In rural areas, $13 \%$ of respondents did not attend schools, $64 \%$ are elementary and junior high school graduates, and $23 \%$ are high school graduates. education.

In density, both urban and rural are relatively similar with 4-5 members of every household. The majority of respondents in urban areas are civil servants and non-civil servants; while mostly farmers in rural areas. The types of food crops are corn, rice, sorghum, tubers and various types of beans.

\section{Household expenses}

The household expenses are categorized into two, they are: food and non-food. Food expenses is monthly expense to buy various foodstuffs in cash, and non-food expenses are monthly expense for education, housing and facilities, clothing, various goods, and transportation costs. Ojek (public motorbike transport) was calculated monthly.

The following table shows the average expenses per capita in urban and rural households.

Table 1. Average expenses of urban and rural households

\begin{tabular}{|c|c|c|c|c|c|c|c|c|c|}
\hline \multirow[b]{2}{*}{ No } & \multirow{2}{*}{$\begin{array}{l}\text { Expense } \\
\text { category }\end{array}$} & \multicolumn{2}{|c|}{ Urban } & \multicolumn{2}{|c|}{ Rural } & \multicolumn{2}{|c|}{ Research location } & \multirow{2}{*}{$\begin{array}{c}\text { Urban } \\
\%\end{array}$} & \multirow{2}{*}{$\begin{array}{c}\text { Rural } \\
\%\end{array}$} \\
\hline & & IDR/month & $\%$ & IDR/month & $\%$ & $\begin{array}{c}\text { Total } \\
\text { IDR/month }\end{array}$ & $\%$ & & \\
\hline 1 & Food & $1,365,444$ & 60.05 & 564,813 & 59.16 & $1,930,257$ & 60 & 70.74 & 29.26 \\
\hline \multirow[t]{2}{*}{2} & Non-food & 908,523 & 39.95 & 389,899 & 40.48 & $1,298,422$ & 40 & 69.69 & 30.03 \\
\hline & Families & $2,273,966$ & 100 & 954,711 & 100 & $3,228,679$ & 100 & 70.43 & 29.57 \\
\hline 1 & Food & 341.361 & 60.05 & 141.453 & 59.16 & 482.814 & 60 & 70.70 & 29.30 \\
\hline \multirow[t]{2}{*}{2} & Non-food & 227.131 & 39.95 & 97.475 & 40.84 & 324.606 & 40 & 60.67 & 30.03 \\
\hline & Per capita & 568.492 & 100 & 238.298 & 100 & 807.402 & 100 & 70.41 & 29.59 \\
\hline
\end{tabular}

Source: Analyzed primary data, 2020.

92 
It can be seen from Table 1 that partial food expenses were $60.05 \%$, and non-food expenses were $39.95 \%$ in urban areas. In rural areas, food expenses were $59.16 \%$ and non-food expenses were $40.48 \%$. Proportionally, non-food expenses in rural areas were slightly larger than those of urban areas. This finding reflects collective cooperation and close community in rural life where hardships resolved together. Among the collective activities are traditional gathering, death ceremonies, marriages, and celebrations (Suek, 2018). In urban area, life tends to be heterogeneous and individual where less social expense was expected, contrasted to the people of rural area.

Overall food expenses in both locations reached $60 \%$ and $40 \%$. By the ratio of total expenses in the two regions, food expenses in urban areas are almost three times of rural areas. This finding reflects that most types of food in urban areas are purchased, different from rural areas that are mostly sourced from farming production. On a bigger scale, the the total value of non-food expenses in urban areas was almost 2.5 times bigger than rural areas. Even so, the partial proportion of non-food expenses in rural areas was $0.53 \%$ greater than urban areas $(40.48 \%$ - 39.95). These differences were affected by the diverse spending living in the city where household expenses may bigger than in rural areas. This finding lent a strong support to Hildayanti, Jenahar, \& Oemar (2017) who found that household expenses are influenced by income and the number of household members.

According to BPS of Kabupaten Malaka (2019), per capita's expenses for food and non-food were IDR $373,084 /$ month and IDR 235,046/month. This amount was greater than the food and non-food expenses in the two research locations. This pattern appears to follow Engel's Law where a greater income leads to a smaller food expense. Conversely, a smaller income leads to a lesser food expense.

It can be concluded that both urban and rural areas of Kabupaten Malaka have relatively low welfare. In this case, their welfare is strongly influenced by the economic access to food, which further affects food's quality and quantity consumed. This result is in line with Arida et al., (2015) where household welfare is reflected through the proportion of food expenses, which is higher than the proportion of non-food expenses. In line with Engel's Law, Heriyanto (2018) wrote that higher income level likely leads to decreased food expenses, and vice versa. In this study, high proportion of food expenses were caused by low income, in which households prioritized fulfilling food needs over other needs. Similar to a study by Rahmansyah (2020), it is evident that food expenses in Kabupaten Malaka is high.

\section{Staple food availability}

One of the main aspects in building food security is food availability (Mariyani et al., 2017) where the availability of staple food in a household becomes a reference for the amount of food available. Availability of staple foods analyzed in this study are corn, rice, and sorghum. Respondents' efforts in meeting the availability of staple food were in the forms of own farming production, purchases, and aids from relatives. Apart from own cultivation to get the type of food they want, people can get food by buying it (Sugiarti \& Gita, 2020). Staple food availability in this research did not include rice subsidized by the government (raskin). This leaves a room for further research to take into account the availability of raskin as a staple food.

In terms of sources, $76.66 \%$ of households in urban areas obtained staple food from solely buying, and $11.65 \%$ from the combination of buying and aids from relatives. A total of $6.68 \%$ obtained staple food from the combination of own farming and buying. The remaining $1.67 \%$ obtained staple food from the combination of farming, buying, and aids from relatives. On the other hand, $61.67 \%$ of rural households obtained staple food from farming and buying; $3.33 \%$ obtained staple food from the combination of farming, buying, and aids from relatives. The remaining $33.67 \%$ obtained staple food solely from farming. This finding is line with the study by Rahayu (2014) where availability of staple food in rural areas mostly comes from own farm production. 


\section{Staple food availability and consumption period}

Based on the staple food availability and consumption period, it was found that the staple food availability for urban households comes from own production of $834 \mathrm{~kg} / \mathrm{year}$ with an average consumption period of 294 days. From the number of purchases per year, it was found that the availability of corn, rice, and sorghum is $560 \mathrm{~kg}, 9 \mathrm{~kg}$, and $11 \mathrm{~kg}$ respectively with the consumption periods of 235 days, 3 days and 5 days. From the relatives' aids, the availability of rice is $18 \mathrm{~kg}$ and corn is $15 \mathrm{~kg}$, with a consumption period of 7 days and 5 days, respectively. It can be concluded that the staple food availability for urban households is mostly through purchases, yet not sufficient for consumption periods of 365 days. This is in line with Mbana et al., (2015) who states that various strategies are pursued to meet these needs for a year.

Availability and consumption period of rural households for annual production of rice, corn and sorghum are $285 \mathrm{~kg}, 203 \mathrm{~kg}$ and $136 \mathrm{~kg}$, respectively, with a consumption period of 302 days, 78 days, and 63 days, respectively. The amount of rice purchased was $641 \mathrm{~kg}$ with a consumption period of 235 days. Shorgum is purchased as much as $10 \mathrm{~kg}$ with a consumption period of 5 days. It can be concluded that the staple food availability in rural areas is sufficiently coming from rice for 235 days, with corn and sorghum as back-ups during the remaining time until the next harvest season. This follows a study by Gunadi and colleagues (2018) where rice is the main food source for rural households.

Hence, the strategies used by households to meet annual food availability are: 1) adaptive by reducing food portions, switching to cheaper food, looking for additional jobs; 2) selling assets such as cattle, buffalo, chickens, and pigs; 3) using available seeds, in which some are consumed; and 4) selling/ pawning agricultural equipment. It is noteworthy that the fourth strategy is only carried out by a small number of households.

\section{Energy availability in households}

The average energy availability of per capita urban households in the forms of rice, corn, and sorghum is $1,539 \mathrm{kcal}, 26 \mathrm{kcal}$ and $24 \mathrm{kcal}$, respectively. These numbers are considered low. Based on the classification of food adequacy stability by Soemarno (2010) the majority of urban households (95\%) are on inadequate staple food, while the remaining $5 \%$ are on adequate basic food availability. In the rural househols, per capita's energy availability of rice, corn, and sorghum are 1,539 kcal, $495 \mathrm{kcal}$ and $302 \mathrm{kcal}$, respectively. These numbers are considered high as they are exceeding the national energy availability of 2,200 $\mathrm{kcal} / \mathrm{capita} / \mathrm{day}$. Such high availability might be caused by the food resources from own farm production. However, the disparity is quite high where average energy availability is not evenly distributed, considering that $80 \%$ of households are classified as inadequate. That leaves only $20 \%$ of households have adequate availability of basic food energy. Hence, this present study concluded that the average availability of basic food energy for rural households is higher than urban households.

\section{Consumption pattern, habit, and meal frequency}

Patterns of food consumption include portions, types of food consumed, eating habits and food management. Such patterns are highly determined by the number of family members, parents' education, income, and the availability of family food (Satmalawati Endah, 2016). Household eating habits are influenced by attitudes towards food, customs, and religion. In example, rural farmers prefer to eat rice plus side dishes; while urban households tend to consume congee, local food, and snacks. Daily pattern of food consumption in both urban and rural households is relatively similar, where rice and corn are the main meal plus side dishes. Generally, the consumption pattern is dominated by carbohydrate food sources.

In terms of eating frequency, Adha \& Suseno (2020) stated that the amount and type of food determine humans' level of energy sufficiency in a day where eating frequency is among the important aspects of diet.

94

Nahak et.al (Comparison of Staple Food Availability and Urban and Rural....., Household, Urban, Rural, Availability) 
The average eating frequency of both urban and riural households are three-times big meals including breakfast, lunch, and dinner, and additional snacks.

\section{Meal pattern expectations}

Meal pattern expectations (MPE) (Pola Pangan Harapan/PPH) refers to the prepared main food groups where the required calories and nutrients are met according to the body's needs (Saputro \& Fidayani, 2020). In WNPG X (2013), the recommended energy intake is $2,150 \mathrm{kcal} / \mathrm{cap} /$ day. Results of this study shows that the average actual energy consumption (AEC) of rural households was 2,169 kcal/cap/day, which exceeds the normal AEC. On the other hand, the AEC of urban households is $1.990 \mathrm{kcal} / \mathrm{cap} / \mathrm{day}$, which is smaller than the normal AEC. These findings are in line with Damora and colleagues (2008) where the average energy consumption of a farmer household reached $2,020 \mathrm{kcal} / \mathrm{cap} / \mathrm{day}$. The data from their study exceeds the recommended figure at that time, which was $2,000 \mathrm{kcal} / \mathrm{cap} / \mathrm{day}$. The following Table 2 summarizes the expected food pattern index for households in urban and rural areas.

Tabel 2. Results of Meal Pattern Ex[ectation (MPE) in the respondents' households

\begin{tabular}{|c|c|c|c|c|c|c|c|}
\hline \multirow[b]{3}{*}{ No } & \multirow[b]{3}{*}{ Food group } & \multicolumn{4}{|c|}{ MPE composition } & \multicolumn{2}{|c|}{ National MPE } \\
\hline & & \multicolumn{2}{|c|}{ Urban } & \multicolumn{2}{|c|}{ Rural } & \multirow[b]{2}{*}{$\begin{array}{c}\text { Energy } \\
\text { (kcal) }\end{array}$} & \multirow[b]{2}{*}{$\begin{array}{l}\text { MPE } \\
\text { score }\end{array}$} \\
\hline & & $\begin{array}{c}\text { Energy } \\
\text { (kcal) }\end{array}$ & $\begin{array}{l}\text { MPE } \\
\text { score }\end{array}$ & $\begin{array}{c}\text { Energy } \\
\text { (kcal) }\end{array}$ & $\begin{array}{l}\text { MPE } \\
\text { score }\end{array}$ & & \\
\hline 1 & Grains & 835 & 19.4 & 1,002 & 23.3 & 1,075 & 25 \\
\hline 2 & Tubers & 137 & 2.5 & 375 & 2,5 & 129 & 2.5 \\
\hline 3 & Animal source food & 132 & 12.3 & 80 & 7.5 & 258 & 24 \\
\hline 4 & Oil \& fat & 239 & 5 & 121 & 2.8 & 215 & 5 \\
\hline 5 & Oily fruits \& seeds & 170 & 1 & 192 & 1 & 64.5 & 1 \\
\hline 6 & Nuts & 418 & 10 & 332 & 10 & 107.5 & 10 \\
\hline 7 & Sugar & 26 & 0.6 & 27 & 0.6 & 107.5 & 2.5 \\
\hline 8 & Fruits \& vegetables & 33 & 7.6 & 41 & 9.5 & 129 & 30 \\
\hline 9 & Others & 0 & 0 & 0 & 0 & 64.5 & 0 \\
\hline & Total & 1,990 & 58.4 & 2,169 & 57.2 & 2,150 & 100.0 \\
\hline
\end{tabular}

It can be seen from the Table 2 that the score for urban households is 58.4 higher than the rural household, which is 57.2. However, the MPE score in both locations is below the national MPE target of 100 . This finding lend a astrong support to a study by Hamid and colleagues (2013) where MPE score for rural households is averagely 60.27 , and urban households is 82.14 . its is indicated that the household consumption in both urban and rural areas has never been diverse, in which less attention to the quantity and quality of food consumed has been paid. Both rural and urban households must pay attention to a balance consumption patterns to meet adequate nutritional needs. This expectation follows Mustopa (2019) where diversification of food consumption must meet sufficient nutritional content, in which rice can be substituted for other staple foods such as corn and cassava.

The higher MPE score of urban households compared to rural households means better food quality in urban households. As can be seen from MPE score against the normal MPE, grains, tubers, oily fruit/seeds, animal foods, oils and fats, and nuts provide the largest contribution. However, all these food groups have not yet reached the national average. It means that the food quality in both urban and rural households require improvement by taking into account the maximum limit of MPE score. In other words, food consumption of both rural and urban houses must be diversified. The push for food quality improvement is in line with Poernomo \& Winarto (2020) who state that diversification can reduce dependence on one type of food, and help fulfill nutritional needs. 


\section{The comparison of staple food availability in the households}

Comparison of staple food availability is obtained by converting various staple foods into the equivalent of rice. Differences in the availability of staple food in urban and rural households were tested for the average difference (z-test). Results show that the average availability of staple food in rural and urban households was significantly different at $<0.05$. This means that the availability of staple food for rural households is greater than that of urban households. However, the existing availability does not guarantee the quality of food consumption. This might be due to the variation in staple food sources of carbohydrates, which are more widely available in rural areas rather than urban households. This result echoes Apriani dan Baliwati (2011), who found that the amount of food availability in rural areas is higher, but not significant at $p>0.05$. The availability of staple food per capita in rural areas is higher than urban areas although the MPE score of urban households are greater than that of rural households.

\section{Food security in the households}

Food security is measured through the stability and security of staple food availability in a household (Faatihah et al., 2021). Food insecurity refers to a situation where a person does not have physical, social, and economic access to sufficient food (Wardani, et,al., 2018). Furthermore, various, safe, and nutritious staple food is absolutely required for a healthy and active life. Meanwhile, the aspect of the proportion of food expenditure and energy consumption are used to determine household food security.

The distribution of household food security in Table 3 follows Bickel et al., (2000). It is said that in urban food security, there are 32 (53.33\%) households belong to the food security category; 20 (33.33\%) households belong to the food insecurity category with mild hunger levels; $5(8.33 \%)$ households belong to the food insecurity category with moderate hunger levels; and the remaining $3(5 \%)$ household belong to the food insecure category with severe hunger levels.

There are $7(11.67 \%)$ food security households in rural households; 34 (56.67\%) belong to the insecurity category with mild hunger levels; $14(23.33 \%)$ households belong to the food insecurity category with moderate hunger levels; and the remaining $5(8.33 \%)$ households belong to the food insecure category with severe hunger levels.

Table 3. Respondents' Household Food Security

\begin{tabular}{rlrrrr}
\hline No & Food security category & \multicolumn{2}{c}{ Urban } & \multicolumn{2}{c}{ Rural } \\
\cline { 3 - 6 } & $\begin{array}{c}\text { Numbers } \\
\text { of } \\
\text { household }\end{array}$ & $\begin{array}{c}\text { Percentage } \\
\text { (\%) }\end{array}$ & $\begin{array}{c}\text { Numbers } \\
\text { of } \\
\text { household }\end{array}$ & $\begin{array}{c}\text { Percentage } \\
\text { (\%) }\end{array}$ \\
\hline 1 & Secure & 32 & 53.33 & 7 & 11.67 \\
2 & Insecure with low hunger level & 20 & 33.33 & 34 & 56.67 \\
3 & Insecure with mild hunger level & 5 & 8.33 & 14 & 23.33 \\
4 & Insecure with severe hunger level & 3 & 5.00 & 5 & 8.33 \\
\hline \multicolumn{1}{r}{ Total } & 60 & 100.00 & 60 & 100.00 \\
\hline
\end{tabular}

Source: analyzed primary data, 2020

It can be seen from the table that urban households are more food secure than the rural ones. This condition is presumably due to the relatively available cash income, where urban households can buy a variety of other types of food besides carbohydrates. They can purchase other foods with protein and others. This analysis follows Saputri and collaegues (2016) where high food security is determined by the ability of households to access it. Hence, urban households' ability to access food sources other than carbohydrates secure the family members despite the $27(46.34 \%)$ urban households are categorized as severe to mild hunger.

96

Nahak et.al (Comparison of Staple Food Availability and Urban and Rural....., Household, Urban, Rural, Availability) 
Moreover, although rural households have quite a variety of food sources from carbohydrates, their access to protein and other food sources is relatively limited. This may be influenced by their dependence on the largest cash income in the forms of agricultural production, where they must decide on the use of agricultural products for household consumption to meet subsistence needs versus for sale. This finding is in line with Sari (2017) about reasons behind low food security of rural households. In this study, the percentage of household food security in urban areas was greater than that of rural areas. It contradicts a study by Ashari and colleagues (2017) where the number of food insecure rural households was $27.1 \%$, slightly higher than urban households of $18.8 \%$. Our study evidences that the household's knowledge about food diversification is relatively low. It is noteworthy that knowledge on food diversification will help households in determining the quality of food. An understanding of food diversification is important because rural households mostly think that food security is determined by the numbers of rice consumption, or are dominated by carbohydrates.

\section{Conclusion}

A. The availability of staple food for both urban and rural households was insufficient for a period of 365 days.

B. The ACE of rural households is 2,169 kcal/cap/day, which is higher than that of of urban households with $1,990 \mathrm{kcal} / \mathrm{cap} / \mathrm{day}$. On the other hand, the MPE score of urban households was 58.4 . which is greater than that of the rural gouseholds with 57.2. However, the MPE scores of both urban and rural households are lower than the national MPE score of 100.

C. The average household staple food availability in urban areas is $604 \mathrm{~kg} / \mathrm{year}$, which is significantly $(a<0.05)$ lower than the average staple food availability for rural households of $678 \mathrm{~kg} / \mathrm{year}$.

\section{REFERENCES}

Adha, A. S. A., \& Suseno, S. H. (2020). Pola Konsumsi Pangan Pokok dan Kontribusinya Terhadap Tingkat Kecukupan Energi Masyarakat Desa Sukadamai. Jurnal Pusat Inovasi Masyarakat, 2(6), 988-995.

Apriani, S., \& Baliwati, Y. F. (2011). Faktor-Faktor Yang Berpengaruh Terhadap Konsumsi Pangan Sumber Karbohidrat Di Perdesaan Dan Perkotaan. Jurnal Gizi dan Pangan, 6(3), 200. https://doi.org/10.25182/jgp.2011.6.3.200-207

Apu, R. T., Pellokila, M. R., \& Nainiti, S. P. N. (2017). Strategi Pemenuhan Kebutuhan Pangan Pokok pada Rumah Tangga di Desa Noelbaki Kecamatan Kupang Tengah Kabupaten Kupang. Skripsi. Program Studi Agribisnis, Fakultas Pertanian, Universitas Nusa Cendana.

Arida, A., Sofyan, S., \& Fadhiela, K. (2015). Analisis Ketahanan Pangan Rumah Tangga Berdasarkan Proporsi Pengeluaran Pangan Dan Konsumsi Energi (Studi Kasus Pada Rumah Tangga Petani Peserta Program Desa Mandiri Pangan Di Kecamatan Indrapuri Kabupaten Aceh Besar). Jurnal Agrisep, 16(1), 20-34.

Ashari, C. R., Khomsan, A., \& Baliwati, Y. F. (2017). Studi Analisis Ketahanan Pangan Rumah Tangga Miskin Perkotaan Dan Perdesaan Di Sulawesi Selatan. Jurnal Ketahanan pangan. Diambil dari http://repository.ipb.ac.id/handle/123456789/85393

Badan Pusat Statistik. (2019). Kabupaten Malaka dalam Angka 2019. Kabupaten Malaka. https://doi.org/11020015321

Banita, D. (2013). Analisis Ketersediaan Pangan Pokok dan Pola Konsumsi pada Rumah Tangga Petani di Kabupaten Wonogiri. Skripsi. Program Studi Agribisnis, Fakultas Pertanian, Universitas Sebelas Maret Surakarta.

Bickel, G., Nord, M., Price, C., Hamilton, W., \& Cook, J. (2000). Guide to Measuring Household Food Security Revised 2000. In Office of Analysis, Nutrition, and Evaluation.

BKP. (2015). Panduan Penghitungan Pola Pangan Harapan (PPH). Badan Ketahanan Pangan Kementerian Pertanian.

Damora, A. S. U., Anwar, F., \& Heryatno, Y. (2008). Pola Konsumsi Pangan Rumah Tangga Petani Hutan Kemasyarakatan Di Kabupaten Lampung Barat. Jurnal Gizi dan Pangan, 3(3), 227. https://doi.org/10.25182/jgp.2008.3.3.227-232

Dewi Y dan Purwadiani N. (2015). Studi Pola Konsumsi Makanan Pokok pada Penduduk Desa Pagendingan 
Kecamatan Galis Kabupaten Pamekasan Madura. E-Journal Boga, 4(3), 14.

Dinas Tanaman Pangan, H. dan P. (2019). Balai Penyuluhan Kecamatan Malaka Tengah Wilayah Kerja Penyuluhan Pertanian Desa Wehali dan Desa Naimana. In Programe Penyuluhan Pertanian. Kabupaten Malaka.

Faatihah, A., Sukayat, Y., Setiawan, I., \& Judawinata, M. G. (2021). Keterpurukan Dan Kebangkitan Pertanian Strategi Mempertahankan Ketersediaan Pangan Pokok Rumah Tangga Petani Padi Pada Masa Pandemi Covid-19. Jurnal Pemikiran Masyarakat IImiah Berwawasan Agribisnis, 7(1), 309-319.

Fallo, Y., Lango, A., \& Hendrik, E. (2019). Akses Dan Ketersediaan Pangan Pokok Pada Rumah Tangga Petani Di Desa Napi Kecamatan Kie Kabupaten Timor Tengah Selatan. Jurnal Buletin Excellentia, VIII(1), 52-59.

Gunadi, F., Sjarief, R., Nazli, S., Intan, E., Putri, K., \& Noorachmat, B. P. (2018). Analisis Faktor-Faktor Teknologi dan Sosial Budaya yang Mengancam Keberlanjutan Kemandirian Pangan Pokok di Provinsi Jawa Barat , Indonesia. Journal of Natural Resources and Environmental Management, 9(3), 658-670.

Hamid, Y., Setiawan, B., \& Suhartini, S. (2013). Analisis Pola Konsumsi Pangan Rumah Tangga. Agrise, XIII(3), 1412-1425.

Heriyanto Heriyanto. (2018). Permintaan Pangan Rumahtangga Provinsi Riau: Model Linear Approximate Almost Ideal Demand System. Jurnal Agribisnis, 20, 159-167.

Hildayanti, S., Jenahar, T., \& Oemar, H. (2017). Faktor-Faktor Yang Mempengaruhi Pengeluaran Rumah Tangga Petani Karet Di Kabupaten Banyuasin Sumatera Selatan. Jurnal Ecoment Global, 2(2), 57-62.

Mariyani, Adawiyah, \& Prasmatiwi. (2017). Ketersediaan Pangan Dan Faktor-Faktor Yang Mempengaruhi Ketersediaan Pangan Rumah Tangga Petani Padi Anggota Lumbung Pangan Di Kecamatan Ambarawa Kabupaten Pringsewu. JIIA, 5(3), 304-311.

Mbana, F., Seran, S., \& Nikolaus, S. (2015). Analisis Tingkat Ketersediaan dan Pola Konsumsi Pangan Pokok Rumah Tangga Petani di Desa Oeltua Kecamatan Taebenu Kabupaten Kupang. Skripsi. Program Studi Agribisnis, Fakultas Pertanian, Universitas Nusa Cendana.

Mustopa M. (2019). Diversifikasi Konsumsi Pangan Pokok Dalam Mewujudkan Ketahanan Rumah Tangga Di Desa Mekar Sari Kecamatan Pelawan Kabupaten Sarolangun. Skripsi. Program Studi Ekonomi Syariah, Fakultas Ekonomi dan Bisnis Islam, Universitas Islam Negeri Sultan Thaha Saifuddin Jambi.

Pellokila, M. R., Oematan, G., \& Kami, R. N. L. (2020). Hubungan faktor sosial ekonomi dengan ketersediaan pangan rumah tangga petani di kecamatan malaka tengah kabupaten malaka. Jurnal PAZIH_Pergizi Pangan DPD NTT, 9(2).

Poernomo, A., \& Winarto, H. (2020). Kemapuan Produksi Sumber Pangan Pokok Dan Non Biji- Bijan Terhadap Ketahanan Pangan. Majalah Ilmiah Manajemen dan Bisnis, 17(2), 1-12.

Pratiwi, M. A., Seran, S., \& Bano, M. (2016). Keragaan Ketahanan Pangan Pokok Rumah Tangga Di Kecamatan Wewiku Kabupaten Malaka. Skripsi. Program Studi Agribisnis, Fakultas Pertanian, Universitas Nusa Cendana.

Rahayu, W. (2014). Ketersediaan Pangan Pokok pada Rumah Tangga Petani Padi Sawah Irigasi dan Tadah Hujan di Kabupaten Karanganyar. Jurnal Agrisep, 7(1), 45-51.

Rahmansyah Z, et al. (2020). Analisis Ketahanan Pangan Rumah Tanggamiskin Berdasarkan Pangsa Pengeluaran Pangan Dankonsumsi Energi Di Desa Girirejo Kecamatan Imogirikabupaten Bantul. Jurnal Dinamika Sosial Ekonomi, 21(1), 68-78.

Saputri, R., Lestari, L. A., \& Susilo, J. (2016). Pola konsumsi pangan dan tingkat ketahanan pangan rumah tangga di Kabupaten Kampar Provinsi Riau. Jurnal Gizi Klinik Indonesia, 12(3), 123-130.

Saputro, W. A., \& Fidayani, Y. (2020). Determinan Pola Pangan Harapan Pada Keluarga Petani Di Kabupaten Klaten ( Studi Kasus Desa Mandiri Pangan ). Seminas Nasional dan Call For Paper, 231-237.

Sari, N. A. (2017). Ketahanan Pangan Tingkat Rumah Tangga Perkotaan dan Perdesaan di Kabupaten Kutai Kartanegara. JEMI, 17(1), 8-17.

Satmalawati Endah, F. M. (2016). Diversifikasi Konsumsi Pangan Pokok Berbasis Potensi Lokal dalam Mewujudkan Ketahanan Pangan di Kecamatan Insana Barat Kabupaten Timor Uengah utara. Lembaga Penelitian Dan Pemberdayaan Masyarakat (Lppm) Unmas Denpasar, (11), 1018-1027.

Soemarno. (2010). Strategi Pemenuhan Kecukupan Pangan Rumahtangga.

Sudjana. (2002). Metode statistika (hal. 508 hlm). hal. 508 hlm. Bandung: Bandung: Tarsito, 2002. https://doi.org/979-9185-18-1

98 
Suek, J. (2018). Risiko, Inefisiensi dan Keberlanjutan Sistem Wanatani Mamar di Wilayah Timor Barat. Disertasi. Program Pasca Sarjana, Fakultas Pertanian, Universitas Gadjah Mada, Yogyakarta.

Sugiarti, R., \& Gita, D. (2020). Diversity Of Food Consumption Of Alternative Food Community Jember Regency. Jurnal Biologi dan Pembelajaran Biologi, 5(1), 42-51. https://doi.org/10.32528/bioma.v5i1.3687

Wardani, S., Adyatma, \& Kumalati, R. (2018). Analisis Proporsi Pengeluaran Pangan Dan Konsumsi Pangan Dengan Ketahanan Pangan Rumah Tangga Petani Di Kecamatan Sungai Tabuk Kabupaten Banjar. Skripsi. Program Studi Pendidikan Geografi, Fakultas Keguruan dan IImu PendidikanUniversitas Lambung Mangkurat. 